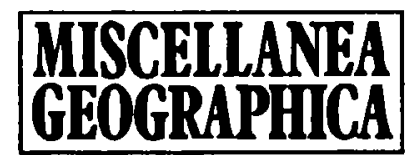

WARSZAWA 1994 Vol. 6

Danuta Kosmowska-Suffczyńska

\title{
LATE QUATERNARY TECTONICS AND DEGLACIATION. A CASE STUDY OF THE SZYDEOWIEC REGION (NE Margin of the Holy Cross Mts)
}

The problem of the configuration of fluvioglacial forms depending on small tectonic structures of the sub-Quaternary substratum analyzed in this article seems apparently unjustified. However, due to occurrence in Poland of a characteristic area of NE margin of the Holy Cross Mountains, where two types of relief are encountered side by side: rock and glacial type, the relation between the two phenomena was ascertained.

The problem of dependence of Quaternary forms and deposits on the relief of the substratum has been widely discussed in literature; however, the direction of the Pleistocene relief, and particularly directions of glacial forms coupled with tectonic features of the given area have not been considered much. The exceptions include i.a. reports from the Eódź Upland indicating the coincidence of direction of large kame forms with structural directions of the basement (e.g. Klajnert 1984).

The field investigations conducted in the vicinity of Szydłowiec as well as statistical comparison of the longer axes of glacial hills, dislocation lines and joint fractures, allowed the author, unlike Klajnert, to find a different dynamics of deglaciation process dependent on the manifestation of late Quaternary tectonics. The forms in question are situated close to the maximum extent of the Odra ice-sheet of Middle Polish (Riss) glaciations. They are conspicuously small, though their slopes are well marked and often interspersed with tiny kame hills (Kosmowska-Suffczyńska 1989, Fig.1). Their longer axis usually ranges from several dozen to several hundred metres (mostly 300 to $600 \mathrm{~m}$ ), and their relative height amounts to $20-25 \mathrm{~m}$. They are built of glaciofluvial material of large, though varying, grain size (Kosmowska-Suffczyńska 1989, photo 1-10). Kames in the vicinity of Szydłowiec usually lie on a thin layer of boulder clay, underlain directly by the rock basement (Lias, Dogger, Malm). It is only in NE and $\mathrm{E}$ area under investigation that the underlying Quaternary and Tertiary (terrigenous Tertiary) deposits are thicker (Kosmowska-Suffczyńska 1988, Figs.7, 9; 1989, Fig.7). 
The analysis of directions of the longer axes of kame hills and ridges (Fig.1) has been made on maps scaled 1:10 000 (Lipienice, Pawłów, Szydłowiec, Gąsawy Rządowe, Wymysłów and Kierz Niedźwiedzi sheets). The direction and length of longer axes were measured. Two directions almost perpendicular to each other, that is $\mathrm{NE}$ with the maximum of $50-60^{\circ}$ and $\mathrm{SE}$ with the maximum $120-130^{\circ}$ (Fig.2) were found to be most privileged. Comparison of the prevalent direction of the longer axes of glacial hills with the dislocation lines does not show they are congruent. It is particularly well seen towards NE-SW direction, where the azimuths of dislocation lines are found in the interval of $\mathrm{N} 22$ to $35^{\circ} \mathrm{E}$, while the prevalent directions of the longer axes of kame hills deviate towards the east by $30^{\circ}$. Interestingly, similar results were obtained from the analysis of directions of the valleys (Kosmowska-Suffczyńska 1986).

The lack of a clear-cut correlation between the directions of the kame hills and dislocation lines does not allow us to accept Klajnert's conception. Another argument denying the correlation of directions of the kame forms with dislocation lines in the area under investigation is the fact that they

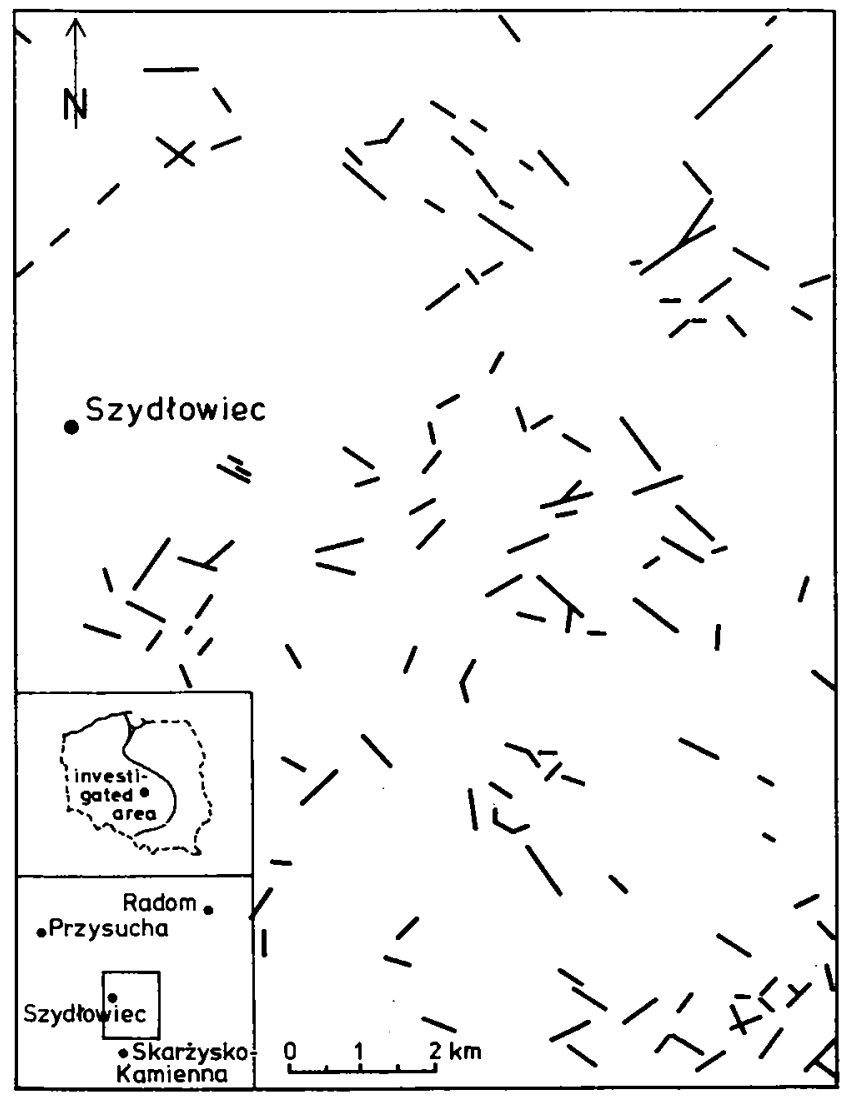

Fig.1. Longer axes of kames 
are extremely scattered (over an area of some $150 \mathrm{sq} . \mathrm{km}$. at least 130 forms can be encountered), the extent of dislocation zones being limited. No larger number of occurrence of kame hills along the dislocation lines was ascertained.

However, the configuration of the kame hills is too homogeneous to be accidental. According to the author, the cause of this non-stochastic configuration of glacial relief is to be found in glacio-isostasy aspects (Liszkowski 1992) of tectonics related to the mesoscopic tectonic structures, which include i.a. joint fractures (Jaroszewski 1972), because in the area under investigation there occurs a striking coincidence of kame directions with the orthogonal system of joints (found on the NE margin of the Holy Cross Mountains by Jaroszewski (1972), both with a transversal set of 25$65^{\circ}$ and with a longitudinal set of $125-155^{\circ}$ (Fig.2).

During the deglaciation of the Odra ice-sheet due to release of the Earth's crust from the ice masses and the emerging tangential stress, the process of the opening of joints (denudational-released joints) occurred. This phenomenon resembled the opening of the joint after the removal of the Cretaceous rocks overlying the Jurassic deposits (Jaroszewski 1972). The opening of joint fissures in the late South Polish glaciation and the early great interglacial period are reported from the Lublin district by Harasimiuk and Henkiel (1981).

The deformation of earth's crust leading to the occurrence of open frac-
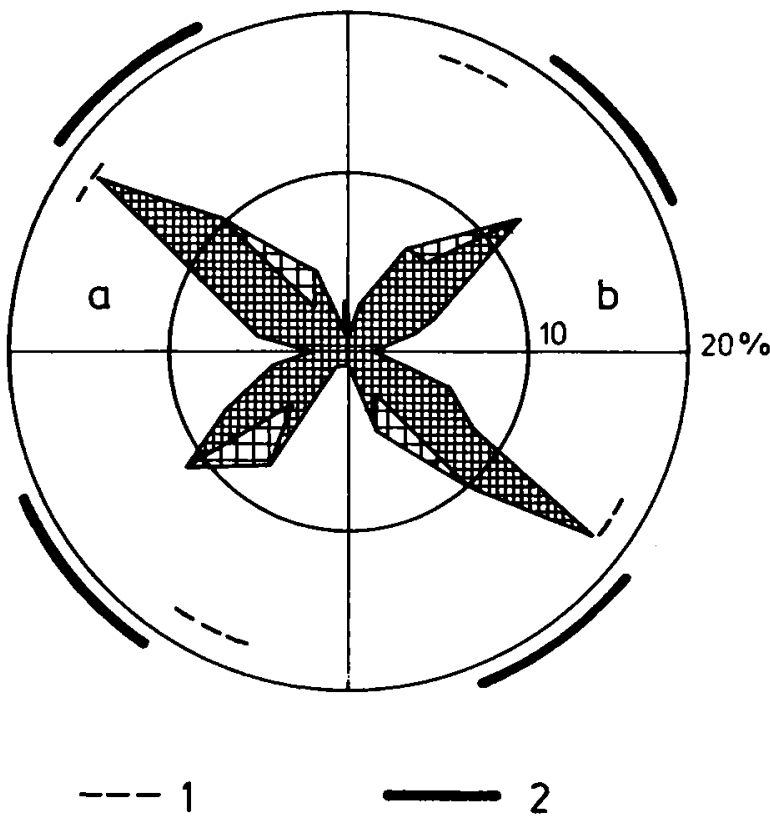

Fig.2. A rosette diagram of directions of longer axes of kames : $a-$ number, $b-$ length, 1 - Extent of directions of tectonic dislocations, 2 - extent of directions of joint fructures 
tured joints was specially well marked in the marginal zone of the ice-sheet (Liszkowski 1982, 1992), and this is the type of the zone in the vicinity of Szydłowiec. They occurred at a time when the ice cover was still in existence (Liszkowski 1992, Mörner, Somi, Zuchiewicz 1989).

The author holds that the occurrence of opened joints in definite directions characteristic of the NE margin of the Holy Cross Mountains imposed the way of areal deglaciation. The joint determined directions and places of occurrence of numerous glaciofluvial kame crevasse forms by creation of zones of a faster disappearance of the ice cover and directions of fluvioglacial water runoff.

\section{REFERENCES}

$\mathrm{Kl}$ ajn ert Z ., 1984, "Analyses of kames for palaeogeographical reconstructions", Boreas 13.

Jaroszewski W., 1972, "Drobnostrukturalne kryteria tektoniki obszarów nieorogenicznych na przykładzie północno-wschodniego obrzeżenia mezozoicznego Gór Świętokrzyskich" (Mesoscopic-structural criteria of tectonics of non-orogenic areas. A case study of NE mesozoic margin of the Holy Cross Mountains, Studia Geol. Pol. 38.

Harasimiuk M., Henkiel A., 1981, "Pokredowa tektonika na pólnocnym skłonie wału metakarpackiego w okolicy Lublina" (Post-Cretaceous tectonics on the $\mathbf{N}$ slope of the Meta-Carpathian embankment near Lublin), Przegl. Geol. 11.

Kosmowska-Suffczyńska D., 1986, "Relationship between relief and tectonics on the NE border of the Holy Cross Mountains", Miscellanea Geographica.

Kosmowska-Suffczyńska D., 1988, "Rzeźba podczwartorzedowa okolic Szydłowca. Rola litologii I tektoniki" (Sub-Quaternary relief in the region of Szydłowiec. The role of lithology and tectonics), Prace i Studia Geogr. 9.

Kosmowska-Suffczynska D., 1989, "O genezie niektórych tzw. suchych dolinek denudacyjnych" (On the origin of some of the so-called dry denudation valleys), Acta Geogr. Łódź. 59.

Liszk owski J., 1982, "Geneza wspołczesnych pionowych ruchów skorupy ziemskiej na obszarze Polski" (The origin of contemporary vertical movements of the earth's crust in Poland), Rozpr.Uniw.Warsz. 179.

Liszkowski J., 1992, "Wpływ pleistoceńskich lądolodów na stan, strukturę, kinematyke i dynamike Ziemi" (The impact of Pleistocene glaciers on the state, structure, kinematics and dynamics of the Earth), Mat.V1I Glacitectonics Symp., Zielona Gora.

Mörner A., Somi E., Zuchiewicz W., 1989, "Neotectonics and Palaeoseismicity within the Stockholm intracratonal region in Sweden", Tectonophysics 163. 